\title{
Prolonged Maintenance Chemotherapy in the Management of Urinary Infection in Childhood
}

\author{
I. C. S. NORMAND,* B.M., M.R.C.P. ; JEAN M. SMELLIE,* B.M., M.R.C.P., D.C.H.
}

Brit. med. F., 1965, 1, 1023-1026

It is now widely recognized not only that urinary infection in childhood is a common and recurrent condition, but also that symptomatic improvement of the acute episode, whether spontaneous or after a short course of chemotherapy, may be followed by persistent asymptomatic infection (Kass, 1956 ; Kunin et al., 1964 ; Dunn et al., 1964). It is also accepted that infection of the urinary tract in childhood may have a serious outcome. De Luca et al. (1963) state that 210 out of 597 children treated intermittently with antimicrobial therapy eventually developed severe renal damage. In a retrospective study of 72 patients admitted to hospital during childhood because of urinary infection, and whose symptoms had started 11 to 27 years earlier, Steele et al. (1963) found that $18 \%$ had died, and a further $30 \%$ had progressive renal insufficiency or persistent urinary infection. Smellie et al. (1964) in a study of 200 children with urinary infection showed that $27 \%$ of those with a history of recurrent infection had radiological evidence of chronic pyelonephritic scarring, and the majority of these dated the onset of their symptoms to the first five years of life. Moreover, the incidence of renal scarring appeared to rise with increasing duration of symptoms. It is evident that the end-result of recurrent urinary infection may frequently be progressive renal damage.

The treatment of urinary infections in children must therefore include an attempt to prevent persistence or recurrence of infection. The use of prolonged maintenance chemotherapy to achieve this has repeatedly been advocated (Stansfeld and Webb, 1954 ; Kass, 1957 ; Beveridge, 1962), and there are encouraging reports of the value of this form of therapy in childhood (Marshall and Johnson, 1959 ; Straffon and Engel, 1960 ; De Luca et al., 1963 ; Holland and West, 1963).

Since 1956 all children with evidence of chronic pyelonephritis attending University College Hospital Paediatric Department have been treated with prolonged maintenance chemotherapy. Increasing awareness of the potential dangers of recurrent urinary infection has led to extension of this practice to all children in whom urinary infection has been diagnosed and they are now treated for a minimum period of six months following control of the acute infection.

Children who have received this form of treatment for at least six months now number 116, and the initial results are presented.

\section{Methods}

One hundred and sixteen children (29 boys, 87 girls) have received continuous maintenance chemotherapy for a minimum period of six months and for up to seven years, following control of their presenting infections. Their ages at the start of treatment ranged from 3 weeks to 12 years. In each case the diagnosis was established by the finding of a significant bacterial growth in a fresh clean specimen of urine. The urine was cultured by a routine semiquantitative method using a standardized loop and spreading technique. It has been described in detail by Guttman and Stokes (1963), who correlated the * From the Department of Paediatrics, University College Hospital,
London. results obtained by this method with pour-plate bacterial counting techniques. The report of a positive urine culture as defined by them corresponded closely with a growth of $10^{5}$ organisms or more per $\mathrm{ml}$. when urine specimens were simultaneously examined by the two methods. Pyuria was also present in each of the 116 children, who comprise all those from a previous study (Smellie et al., 1964) who have remained under our care and have received treatment for at least six months.

The children treated are classified in Table I according to their previous history of infection and their radiological findings at the time of starting treatment. Table II shows the radiological abnormalities that were demonstrated by intravenous pyelography and micturating cystourethrography.

TABLE I.-Maintenance Chemotherapy in 116 Children with Urinary Infections

\begin{tabular}{ccc|c|c|c}
\hline \multicolumn{2}{c|}{ Attacks } & & $\begin{array}{c}\text { Normal } \\
\text { Radiology }\end{array}$ & $\begin{array}{c}\text { Abnormal } \\
\text { Radiology }\end{array}$ & Total \\
\hline Single $\ldots$ & $\ldots$ & $\ldots$ & 31 & 15 & 46 \\
Recurrent & $\ldots$ & $\ldots$ & 19 & 51 & 70 \\
\hline Total & $\ldots$ & $\ldots$ & 50 & 66 & 116 \\
\hline
\end{tabular}

TABLE II.-Radiological Abnormalities in 66 Children Receiving Maintenance Chemotherapy

\begin{tabular}{|c|c|c|c|c|}
\hline & & $\begin{array}{c}\text { Single } \\
\text { Attack } \\
\text { (15 Children) }\end{array}$ & $\begin{array}{c}\text { Recurrent } \\
\text { Attacks } \\
\text { (51 Children) }\end{array}$ & (66 Children $)$ \\
\hline 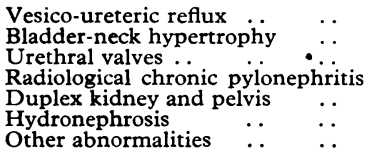 & $\begin{array}{l}\cdots \\
\cdots \\
\cdots \\
\cdots \\
\cdots\end{array}$ & $\begin{array}{r}12 \\
4 \\
1 \\
3\end{array}$ & $\begin{array}{r}34 \\
18 \\
3 \\
19 \\
6 \\
6 \\
6\end{array}$ & $\begin{array}{r}46 \\
22 \\
3 \\
20 \\
9 \\
6 \\
6\end{array}$ \\
\hline
\end{tabular}

The mean age of presentation and of starting treatment in the 46 children with single attacks was 1.9 years, 19 being diagnosed in the first month of life. In the 70 recurrent cases the symptoms with which the child later presented began at a mean age of 4.3 years, and 6.1 years was the mean age at the start of continuous maintenance treatment.

Among the children with radiological abnormalities 26 were treated surgically. Thirteen of these had a period before surgery of at least six months' chemotherapy in maintenance dosage. The operations performed were: ureteroplasty and a plastic operation to the bladder neck, 15 ; ureteroplasty alone, 1 ; bladder-neck plastic operation alone, 1; nephrectomy or heminephrectomy, 7; Hynes-Anderson operation for hydronephrosis, 2 ; nephrolithotomy or ureterolithotomy, 2.

Details of Chemotherapy.-Sulphadimidine or sulphafurazole was the chemotherapeutic agent of choice, and was used in 109 children in a total daily dosage of $0.25 \mathrm{~g}$. under 1 year of age, $0.5 \mathrm{~g}$. from 1 to 5 years, and $1 \mathrm{~g}$. over 5 years. Nitrofurantoin in a dose of $2-4 \mathrm{mg}$. $/ \mathrm{kg}$./day was used exclusively in six children, and nitrofurantoin or ampicillin for varying periods of treatment in a further four children. One child with an associated chronic staphylococcal osteomyelitis received continuous tetracycline. Children with normal radiological findings received 6 to 12 months' treatment in the first instance. In the 
event of a recurrence, maintenance chemotherapy was recommenced for a further 6 to 12 months after control of the acute infection. In children with radiological abnormalities the minimum prescribed period for treatment in most cases was two years, except where radical surgery such as nephro-ureterectomy was likely to have removed all foci of infection, when the minimum period was six months. In many children with anatomical abnormalities it is planned to continue chemotherapy indefinitely. In a few instances nitrofurantoin was not well tolerated on account of vomiting, but no other toxic effects were noted from the use of these drugs.

Follow-up.-A personal follow-up of the children on treatment was made two-weekly, and then monthly for three months initially, or after a recurrence, and then at intervals of two to three months. The examination on each occasion comprised microscopical examination and culture of a fresh clean specimen of urine, record of blood-pressure, clinical history, and measurement of growth.

Presentation of Results.-The number of attacks occurring before the start of treatment was assessed from a detailed history ; a few attacks had been confirmed bacteriologically. In each group of patients the findings are expressed as total number of attacks in the group, occurring over the summated period of patient-years. These are then compared with the number of recurrences during the total period of observation on treatment, and where appropriate, as in children with normal radiology (see Table III), after completion of treatment also. The criteria for diagnosis of a recurrence during maintenance treatment included the presence of a significant bacterial growth in a fresh clean specimen of urine or significant pyuria with symptoms. An infection was also recorded, despite negative urinary findings in our clinic, when there had been a return of the presenting symptoms and the family doctor had instituted full-dosage therapy before the child's next hospital attendance.

\section{Results}

The results of treatment are considered according to the radiological findings or to the previous history of infection. In some children the results will necessarily appear in more than one group; for instance, a child with chronic pyelonephritis may also be included under the headings of radiological abnormalities, recurrent infection, and vesico-ureteric reflux.

\section{Children with Normal Radiology (Table III)}

There were 31 children ( 21 girls, 10 boys) who gave no history of previous urinary infection. They received maintenance chemotherapy for a total of 38 patient-years, and during this time one child had a single recurrence while on treatment and another child had a recurrence within three months of discontinuing treatment. The total period of observations of 12 patients who had discontinued therapy was 18 patient-years. The figure of 38 patient-years of maintenance treatment is influenced disproportionately by one child who had six years' chemotherapy for chronic osteomyelitis; three other children also had prolonged chemotherapy for coincidental repeated infections of the upper respiratory tract.

Nineteen children (17 girls, 2 boys) gave a history of recurrent infection. Before the institution of treatment it was estimated that this group had suffered a total of 70 attacks during a period totalling 31 patient-years since the onset of symptoms. While on treatment three children had a single recurrence each. Eight of these children had completed their prescribed period of maintenance; of these, five each had a single recurrence, all within six months of stopping treatment.

\section{Children with Radiological Abnormalities}

Group A.-There were 15 children (8 girls, 7 boys) in whom there was no history of previous urinary infection (Table IV). Only two children had a single relapse each while on treatment which totalled 22 patient-years. All remain on treatment.

Group B.-The children in this group are those with a history of recurrent infection who were treated by maintenance chemotherapy alone. There were 34 girls and 4 boys. More patients had recurrences while on treatment than in the preceding group, but whereas before treatment the average frequency of attacks was approximately 2.6 per annum (188 attacks in 75 patient-years), on treatment this was reduced to approximately 0.3 per annum (29 recurrences in 95 patientyears). Twenty-five children had no recurrence. On none of these children has treatment been stopped.

Group C.-Twenty-six patients (19 girls, 7 boys) with recurrent infection were treated surgically. Thirteen each received at least six months' continuous maintenance chemotherapy before operation, and for this period of treatment and observation are included in group B above. The other 13 received only short courses of treatment before surgery. All 26 continued with a maintenance regime after operation. Table IV presents a comparison of the incidence of attacks before the start of any form of maintenance therapy (and before surgery) with the incidence of recurrences after discharge from hospital on completion of surgical treatment, while maintenance chemotherapy was being continued. Before treatment there had been 117 attacks during a total period of symptoms of 56 patientyears, and after discharge from hospital there were 25 attacks in 45 patient-years. There was at least one to two weeks' immediate post-operative infection in every case.

TABLE III.-Results of Maintenance Chemotherapy in 50 Children with Normal Radiology

\begin{tabular}{|c|c|c|c|c|c|c|c|c|c|c|c|c|c|}
\hline \multirow{3}{*}{\multicolumn{2}{|c|}{ Attacks }} & \multicolumn{4}{|c|}{ Before Treatment } & \multicolumn{4}{|c|}{ Maintenance Treatment } & \multirow{3}{*}{$\begin{array}{l}\text { Follow-up } \\
\text { Children }\end{array}$} & \multicolumn{3}{|c|}{ After Completion of Treatment } \\
\hline & & \multirow{2}{*}{$\begin{array}{l}\text { No. of } \\
\text { Children }\end{array}$} & \multirow{2}{*}{$\begin{array}{c}\text { Mean } \\
\text { Age at } \\
\text { Onset of } \\
\text { Symptoms }\end{array}$} & \multirow{2}{*}{$\begin{array}{c}\text { Duration } \\
\text { of } \\
\text { Symptoms } \\
\text { Patient- } \\
\text { years }\end{array}$} & \multirow{2}{*}{ Attacks } & \multirow{2}{*}{$\begin{array}{l}\text { Mean } \\
\text { Age at } \\
\text { Start }\end{array}$} & \multirow{2}{*}{$\begin{array}{c}\text { Duration } \\
\text { of } \\
\text { Treatment } \\
\text { Patient- } \\
\text { years }\end{array}$} & \multicolumn{2}{|c|}{ Recurrences } & & \multirow{2}{*}{$\begin{array}{c}\text { Duration } \\
\text { of } \\
\text { Follow-up } \\
\text { Patient- } \\
\text { years }\end{array}$} & \multicolumn{2}{|c|}{ Recurrences } \\
\hline & & & & & & & & No. & $\begin{array}{l}\text { No. of } \\
\text { Children }\end{array}$ & & & No. & $\begin{array}{l}\text { No. of } \\
\text { Children }\end{array}$ \\
\hline $\begin{array}{l}\text { Single } \\
\text { Recurrent }\end{array}$ & $\begin{array}{l}\ldots \\
\cdots\end{array}$ & $\begin{array}{l}31 \\
19\end{array}$ & $\begin{array}{l}1 \cdot 6 \\
4.9\end{array}$ & $\overline{31}$ & $\overline{70}$ & $\begin{array}{l}1 \cdot 6 \\
6 \cdot 4\end{array}$ & $\begin{array}{l}38 \\
30\end{array}$ & $\begin{array}{l}1 \\
3\end{array}$ & $\begin{array}{l}1 \\
3\end{array}$ & $\begin{array}{r}12 \\
8\end{array}$ & $\begin{array}{r}18 \\
7\end{array}$ & $\frac{1}{5}$ & $\frac{1}{5}$ \\
\hline
\end{tabular}

TABLE IV.-Results of Maintenance Chemotherapy in 66 Children with Radiological Abnormalities

\begin{tabular}{|c|c|c|c|c|c|c|c|c|c|}
\hline & & & & fore Treatmer & & & On $\mathrm{I}$ & & \\
\hline & & $\begin{array}{l}\text { No. of } \\
\text { Children }\end{array}$ & Mean Age at & Duration of & Attorle & Mean & Duration of & & rrences \\
\hline & & & Symptoms & Patient-years & Attacks & Start & Patient-years & No. & No. of Children \\
\hline $\begin{array}{lll}\text { Single attacks (A) } & \ldots & \ldots \\
\text { Recurrent attacks } & \ldots & \ldots\end{array}$ & $\cdots$ & 15 & $2 \cdot 4$ & - & 15 & $2 \cdot 4$ & 22 & 2 & 2 \\
\hline $\begin{array}{l}\text { Maintenance alone }(\dot{B}) \\
\text { Surgery and maintenance }(\dot{C})\end{array}$ & $\because$ & $\begin{array}{l}38 \\
26\end{array}$ & $\begin{array}{l}4 \cdot 1 \\
4 \cdot 1\end{array}$ & $\begin{array}{l}75 \\
56\end{array}$ & $\begin{array}{l}188 \\
117\end{array}$ & $\begin{array}{l}6 \cdot 0 \\
6 \cdot 6\end{array}$ & $\begin{array}{l}95 \\
45\end{array}$ & $\begin{array}{l}29 \\
25\end{array}$ & $\begin{array}{r}13 \\
9\end{array}$ \\
\hline
\end{tabular}




\section{Recurrent Infection}

Of 70 children with recurrent infections, 57 received maintenance treatment alone for at least six months; the results are summarized in Table V. There were 258 attacks of infection in 106 patient-years before treatment ( 2.4 attacks per annum per patient) and 32 recurrences in 125 patient-years while on treatment (0.26 infection per annum per patient overall). There were no recurrences in 41 children.

\begin{tabular}{|c|c|c|c|c|c|c|c|}
\hline \multirow[b]{2}{*}{ Radiology } & \multirow[b]{2}{*}{$\begin{array}{l}\text { No. } \\
\text { of } \\
\text { Chil- } \\
\text { dren }\end{array}$} & \multicolumn{2}{|c|}{ Before Treatment } & \multicolumn{4}{|c|}{ On Treatment } \\
\hline & & $\begin{array}{c}\text { Duration } \\
\text { of } \\
\text { Symptoms } \\
\text { Patient- } \\
\text { years }\end{array}$ & Attacks & $\begin{array}{c}\text { Duration } \\
\text { of Treat- } \\
\text { ment } \\
\text { Patient- } \\
\text { years }\end{array}$ & $\begin{array}{l}\text { Recur- } \\
\text { rences }\end{array}$ & $\begin{array}{l}\text { Patients } \\
\text { With } \\
\text { Recur- } \\
\text { rences }\end{array}$ & $\begin{array}{l}\text { Patients } \\
\text { With } \\
\text { No } \\
\text { Recur- } \\
\text { rences }\end{array}$ \\
\hline $\begin{array}{l}\text { Normal } \\
\text { Abnormal }\end{array}$ & $\begin{array}{l}19 \\
38\end{array}$ & $\begin{array}{l}31 \\
75\end{array}$ & $\begin{array}{r}70 \\
188\end{array}$ & $\begin{array}{l}30 \\
95\end{array}$ & $\begin{array}{r}3 \\
29\end{array}$ & $\begin{array}{r}3 \\
13\end{array}$ & $\begin{array}{l}16 \\
25\end{array}$ \\
\hline Total & 57 & 106 & 258 & 125 & 32 & 16 & 41 \\
\hline
\end{tabular}

\section{Vesico-ureteric Reflux}

Forty-six children shown to have vesico-ureteric reflux were treated with maintenance chemotherapy (Table VI). In 12 children there had been only one attack of infection, the condition being recurrent in 34 . Nineteen children were treated surgically, 16 by ureteroplasty, together with bladder-neck repair in all but one, and five nephro-ureterectomies were performed. Nine of the surgical patients received at least six months' preoperative maintenance therapy and for this period are also included in the "maintenance only" group.

\begin{tabular}{|c|c|c|c|c|c|c|c|}
\hline \multirow[b]{2}{*}{ Attacks } & \multicolumn{3}{|c|}{ Before Treatment } & \multicolumn{4}{|c|}{ On Treatment } \\
\hline & $\begin{array}{l}\text { No. } \\
\text { of } \\
\text { Chil- }\end{array}$ & $\begin{array}{l}\text { Dura- } \\
\text { tion } \\
\text { Symp- } \\
\text { toms } \\
\text { Patient- } \\
\text { years }\end{array}$ & Attacks & $\begin{array}{l}\text { Average } \\
\text { Age } \\
\text { Start- } \\
\text { ing } \\
\text { Treat- } \\
\text { ment }\end{array}$ & $\begin{array}{l}\text { Dura- } \\
\text { tion } \\
\text { Treat- } \\
\text { ment } \\
\text { Patient- } \\
\text { years }\end{array}$ & $\begin{array}{l}\text { Recur- } \\
\text { rences }\end{array}$ & $\begin{array}{l}\text { Chil } \\
\text { dren }\end{array}$ \\
\hline Single & 12 & - & 12 & $2.3 \mathrm{yrs}$ & 18 & 1 & 1 \\
\hline $\begin{array}{l}\text { Recurrent ... } \\
\text { Maintenance } \\
\text { only .. } \\
\text { Surgery and } \\
\text { main- } \\
\text { tenance }\end{array}$ & 24 & 44 & 114 & $5.8 \mathrm{yrs}$ & 32 & 18 & 9 \\
\hline
\end{tabular}

In 12 children who had apparently had no previous infection, six starting continuous treatment under the age of 3 months, there was a single recurrence in one child during 18 patientyears' treatment. Twenty-four children receiving maintenance chemotherapy alone were estimated to have had 114 attacks in 45 patient-years before treatment- 2.5 attacks per annum. This was reduced on treatment to 0.37 recurrence per annum.

In 19 patients treated surgically the reduction was from two attacks per patient per annum to approximately 0.8 recurrence ( 25 recurrences in 32 patient-years in 9 children). Two-thirds of the children treated medically and one-half (excluding the immediate post-operative period) of the children treated surgically remained free from infection.

\section{Radiological Chronic Pyelonephritis}

Twenty children with radiological chronic pyelonephritis (Hodson, 1959) have received maintenance chemotherapy for periods up to seven years-six treated exclusively by maintenance sulphonamides, six by chemotherapy followed by surgery with continued maintenance, and in a further eight there was no period of maintenance prior to surgery. In five of the surgical cases nephrectomy or nephrecto-ureterectomy was performed, and in 11 ureteroplasty, with bladder-neck repair in 10. Of the 20 children, 17 also had reflux and have been considered in the previous section, but for convenience the results of therapy in this important group are presented in Table VII. This shows a marked reduction in the incidence of recurrent attacks, despite the presence in all the medically treated children of one or more scarred kidneys.

\begin{tabular}{|c|c|c|c|c|c|c|}
\hline \multirow[t]{3}{*}{ TABLE } & \multirow{3}{*}{$\begin{array}{l}\text { No. } \\
\text { of } \\
\text { Chil- } \\
\text { dren }\end{array}$} & \multirow{2}{*}{\multicolumn{2}{|c|}{$\begin{array}{l}\text { ent of "Chronic } \\
\text { Chemotherapy }(20 \\
\text { Before Treatment }\end{array}$}} & \multirow{2}{*}{\multicolumn{3}{|c|}{$\frac{\begin{array}{l}\text { Pyelonephritis" with } \\
\text { Children) }\end{array}}{\text { On Treatment }}$}} \\
\hline & & & & & & \\
\hline & & $\begin{array}{c}\text { Duration } \\
\text { Patient- } \\
\text { years }\end{array}$ & Attacks & $\begin{array}{c}\text { Duration } \\
\text { Patient- } \\
\text { years }\end{array}$ & $\begin{array}{l}\text { Recur- } \\
\text { rences }\end{array}$ & $\begin{array}{l}\text { Chil- } \\
\text { dren }\end{array}$ \\
\hline $\begin{array}{l}\text { Maintenance alone } \\
\text { Surgery and maintenance }\end{array}$ & $\begin{array}{l}12 \\
14\end{array}$ & $\begin{array}{l}27 \\
35\end{array}$ & $\begin{array}{l}72 \\
70\end{array}$ & $\begin{array}{l}33 \\
23\end{array}$ & $\begin{array}{r}5 \\
10\end{array}$ & $\begin{array}{l}3 \\
5\end{array}$ \\
\hline
\end{tabular}

\section{Discussion}

These results clearly demonstrate the effectiveness of maintenance chemotherapy in reducing the incidence of recurrent urinary infection in childhood. Although the number of attacks occurring before the start of treatment was assessed from the history alone in the majority of cases, only attacks characterized by the same symptoms as those with which the child finally presented were included, and the figure obtained is likely, if anything, to be an underestimate. Moreover, it is difficult to explain the disparity in average age at the onset of symptoms in the children with single attacks (1.9 years) and those with recurrent attacks (4.3 years) unless it is assumed that infection probably occurred earlier in the recurrent group but that the symptoms were not such as to justify making the diagnosis retrospectively.

Children with single infections (see Tables III and IV) presented few problems in their management if a period of chemotherapy of six months or more followed adequate initial treatment. Three out of a total of $46(6.5 \%)$ had a recurrence during 59 patient years' treatment and there was only one relapse during 18 years of follow-up in 12 children who had completed treatment. These results were obtained despite the fact that this group includes 12 children with vesico-ureteric reflux and one who had developed evidence of chronic pyelonephritic scarring after a single severe infection of the urinary tract in the first week of life.

The majority of children with recurrent infection can also apparently be maintained free from infection (Table V). Where there was no radiological abnormality only 3 out of $19(16 \%)$ had each a single relapse on treatment. However, the incidence of recurrence after completion of treatment in patients with normal radiology (Table III) underlines the importance of a follow-up of these apparently normal children. No further relapses occurred after recommencing maintenance treatment.

Treatment was least effective in those children who had had repeated infections previously and who were shown to have abnormalities of the urinary tract (Table V), but even here the reduction in infection was considerable and the number who remained free from recurrence was 25 out of $38(66 \%)$. These children might be expected to do least well. Any underlying abnormality predisposes to recurrences, and patients with these repeated infections would be liable to chronic pyelonephritic scarring (Kleeman et al., 1960 ; Rosenheim, 1963). Moreover, experimental evidence suggests that such scarring would be likely to facilitate further renal infection (De Navasquez, 1956 ; Beeson et al., 1957). It is interesting to note, however, that even in children with scarred kidneys (Table VII) it was possible appreciably to reduce the recurrence rate.

The aim of treatment of urinary infection in children must be to prevent renal scar formation so far as is possible by early diagnosis, adequate treatment of the acute attack, and careful 
follow-up, with continued maintenance therapy where abnormalities are present. This will require a high index of suspicion of the diagnosis throughout the early years of life when urinary infection is common and the symptomatology non-specific (Stansfeld, 1954 ; Burke, 1961 ; and Smellie et al., 1964). It is perhaps noteworthy that the best results were obtained in patients who were treated after apparently their first infection. Their average age at the start of treatment was only 1.9 years, and it is possible that in this group effective treatment was instituted before microscopical or macroscopic scarring of the kidneys had taken place.

Vesico-ureteric reflux was the abnormality found most of ten in this series of 116 children. We are in agreement with Hodson (1962) and Hutch et al. (1963) that reflux predisposes to recurrent urinary infection by producing a false vesical residue and providing an ascending route of infection to the kidney. By maintenance chemotherapy, and by multiple micturition in children old enough to co-operate in this technique (Stephens, 1954), it should be possible to keep the lower urinary tract free from infection and thereby prevent recurrent renal sepsis. Of the 46 children with reflux, 28 showed no radiological evidence of pyelonephritic scarring, 10 of them being aged under 1 year at the time of starting treatment. It is in such children particularly that we hope the effect of chemotherapy may be most beneficial.

Trials of many new chemotherapeutic agents are being reported in the treatment of recurrent urinary infection. Our results were obtained in the majority by the use of sulphonamides, the drugs mainly employed by Straffon and Engel (1960), De Luca et al. (1963), and Örsten (1962). Good results have been reported also by the use of nitrofurantoin (Marshall and Johnson, 1959) and methenamine mandelate (Holland and West, 1963). Perhaps encouragement of the parents to administer the drug and to bring the child for regular follow-up, an integral part of the management, may be as important as the agent used.

The 26 children treated surgically underwent a variety of procedures and were grouped together only for simplicity in the presentation of the results. They tended to be the children with the more complicated lesions. However, each child had at least one week's immediate post-operative infection, and this serves as a reminder that mechanical interference is often followed by this complication. Much of the subsequent infection was symptomless and would not have been appreciated but for the close bacteriological control that was maintained.

The place of ureteroplasty, with or without repair of the bladder-neck, in children with reflux and recurrent infection is not fully established (Scott, 1962 ; Leadbetter, 1963). Refluxstopping operations have not been completely satisfactory as means of preventing infection either in our own small experience or in reported series, and in a review of 100 children in whom ureteric reimplantations were performed Politano (1963) found 26 with persistent urinary infection. Williams (1962, 1963) has repeatedly suggested that these procedures are indicated in children with recurrent infection of the urinary tract only when medical control has failed. Our findings, particularly when the diagnosis is established and maintenance treatment introduced at an early age, indicate that medical treatment can to a large extent eliminate recurrent infection in children with reflux.

The effectiveness of any form of treatment will be known only after prolonged follow-up, and can be judged radiologically in terms of renal growth (Hodson et al., 1962) and regularity of renal outline. A normal rate of growth and prevention of the appearance or extension of renal scars are the ultimate measures of success. However, at this stage we feel that the results of continuous maintenance chemotherapy in the control of urinary infection are encouraging enough to recommend this form of therapy for a minimum period of six months after control of the acute infection in the majority of children, together with a prolonged and vigilant follow-up.

\section{Summary}

One hundred and sixteen children with urinary infections have been treated with continuous maintenance chemotherapy for periods of six months to seven years, using sulphonamides in most of them. The children were seen and their urine was examined at regular intervals, not exceeding three months, throughout treatment. The number of attacks of urinary infection before the start of this treatment was assessed from the history and compared with the incidence of bacteriological recurrences during therapy.

In 50 children with normal radiological investigations there were only four recurrences during a 6- to 12-month period of treatment, although there were recurrences in 6 out of 20 children after completion of their treatment.

In 66 children shown to have radiological abnormalities, maintenance chemotherapy reduced the incidence of infection from an average of approximately 2.5 attacks per patient per annum before treatment to approximately 0.3 recurrence per patient per annum. This group included 46 children with vesico-ureteric reflux and 20 with radiological chronic pyelonephritis, these conditions coinciding in 18 .

The potential value of long-term chemotherapy in the prevention of renal damage is discussed.

We should like to express our thanks to Dr. B. E. Schlesinger, Dr. R. E. Bonham Carter, and Dr. L. B. Strang for permission to study and treat patients under their care ; to Mr. D. R. Davies and $\mathrm{Mr}$. D. Innes Williams for kindly allowing us to follow and treat the children treated surgically; to Dr. C. J. Hodson and Dr. D. Edwards for the radiological studies upon which much of the work is based ; to Dr. E. Joan Stokes and her department for the bacteriological studies; to Sister M. Curtis and Sister M. Whitechurch, of the Children's Department U.C.H., for their unfailing help in the Urinary Infection Clinic ; and to all of these and to Professor M. L. Rosenheim for their continued advice, help, and encouragement.

\section{REFERENCES}

Beeson, P. B., Rocha, H., and Guze, L. B. (1957). Trans. Ass. Amer. Phycns, 70, 120.

Beveridge, J. (1962). Med. 7. Aust., 2, 417.

Burke, J. B. (1961). Lancet, 2, 1116.

De Luca, F. G., Fisher, J. H., and Swenson, O. (1963). New Engl. F. Med., 268, 75.

De Navasquez, S. (1956). f. Path. Bact., 71, 27.

Dunn, P. M., Hine, L. C., and MacGregor, M. E. (1964). Brit. med. F., 1, 1081 .

Guttmann, D., and Stokes, E. J. (1963). Ibid., 1, 1384.

Hodson, C. J. (1959). Proc. roy. Soc. Med., 52, 669.

- (1962). In Renal Disease, edited by D. A. K. Black. Blackwell, Oxford.

Drewe, J. A., Karn, M. N., and King, A. (1962). Arch. Dis. Childh., 37, 616.

Holland, N. H., and West, C. D. (1963). Amer. F. Dis. Child., 105, 560 .

Hutch, J. A., Miller, E. R., and Hinman, F. (1963). f. Urol. (Baltimore), $90,88$.

Kass, E. H. (1956). Trans. Ass. Amer. Phycns, 69, 56.

(1957). Arch. intern. Med., 100, 709.

Kleeman, C. R., Hewitt, W. L., and Guze, L. B. (1960). Medicine (Baltimore), 39, 3.

Kunin, C. M., Deutscher, R., and Paquin, A. (1964). Ibid., 43, 91.

Leadbetter, W. F. (1963). F. Urol. (Baltimore), 90, 700.

Marshall, M., and Johnson, S. H. (1959). f. Amer. med. Ass., 169, 919.

Örsten, P. A. (1962). Acta med. scand., 172, 259.

Politano, V. A. (1963). 7. Urol. (Baltimore), 90, 696.

Rosenheim, M. L. (1963). Brit. med. F., 1, 1433.

Scott, J. E. S. (1962) Proc. roy. Soc. Med., 55, 422.

Smellie, J. M., Hodson, C. J., Edwards, D., and Normand, I. C. S. (1964). Brit. med. Э., 2, 1222.

Stansfeld, J. M. (1954). Proc. roy. Soc. Med., 47, 631.

$\longrightarrow$ and Webb, J. K. G. (1954). Brit. med. F., 1, 616

Steele, R. E., Leadbetter, G. W., and Crawford, J. D. (1963). New Engl. f. Med., 269, 883 .

Stephens, F. D. (1954). Aust. N.Z. F. Surg., 23, 197.

Straffon, R. A., and Engel, W. J. (1960). F. Amer. med. Ass., 174, 1377.

Williams, D. I. (1962). Postgrad. med. F., 38, 520. (1963). In Recent Advances in Paediatric Surgery, edited by A. W. Wilkinson. Churchill, London. 